\title{
Article
}

Claudia Trillo*, Rania Aburamadan, Shatha Mubaideen, Dana Salameen and

Busisiwe Chikomborero Ncube Makore

\section{Towards a Systematic Approach to Digital Technologies for Heritage Conservation. Insights from Jordan}

https://doi.org/10.1515/pdtc-2020-0023

\begin{abstract}
Consensus exists on the importance of heritage for ensuring sustainable futures, due to its impact on political aspects, ethical reflection and local economic development. Nowadays, using technology has become crucial in the construction industry, including heritage conservation. This paper aims to compare a selected sample of digital platforms, gathering data in support of heritage documentation, both for heritage and archeological sites. Despite the huge potential of digital technologies for contributing to heritage conservation, still there is a need for more clarity on what should be used to achieve different goals and what is the best approach under various circumstances. A team of five experts on digital technologies applied to different types of heritage worked collaboratively to gather the case studies in this paper and to analyse them comparatively. Jordan is a Middle East and North Africa country chosen as unit of analysis, because of the huge potential of digital technologies for heritage documentation. The findings from the comparative case review offers a reflection on what should best adopted for achieving different goals. Differences of approaches were revealed between the characteristics of heritage site and those of archaeological sites in Jordan's conservation history. The findings called for a prioritization of using digital technology in both heritage and archeological sites. The discussion on digital platforms currently available in Jordan allows for highlighting strengths and limitations of
\end{abstract}

\footnotetext{
*Corresponding author: Claudia Trillo, School of Science, Environment and Engineering, University of Salford, Salford, UK, E-mail: c.trillo2@salford.ac.uk

Rania Aburamadan, Middle East University, Amman, Jordan Shatha Mubaideen, Council for British Research in the Levant, Amman, Amman, Jordan

Dana Salameen, Department of Antiquites, Amman, Jordan Busisiwe Chikomborero Ncube Makore, School of Science, Environment and Engineering, University of Salford, Salford, UK. https://orcid.org/0000-0001-8943-2093
}

different approaches and methodologies, thus drawing lessons for addressing the strategic choice of the most appropriate digital solution under different circumstances and in different contexts.

Keywords: heritage, digital technology, Jordan, heritage conservation, archaeology

\section{Introduction: Heritage Conservation and Digital Resources: An Overview. Research Problem and Aim of this Study}

There is increasing agreement in international discourse on the crucial role cultural heritage in contributing to the creation of sustainable futures (Hosagrahar et al. 2016; Nocca 2017; Wang et al. 2018). Cultural heritage has multidimensional impacts on the socio-political urban environment and local economic development (Delanty 2010; Harvey 2001, 2008; Smith 2006). Preserving heritage is crucial and valuable for contemporary societies, because of its interconnection with cultural diversity, social stability, identity, resiliency and local economic prosperity (Barrère 2016; Calligaro 2014; Graham, Ashworth, and Tunbridge 2000; Udeaja et al. 2020; Viejo-Rose 2015).

The importance of heritage to achieve sustainable futures has been acknowledged explicitly within the framework of Agenda 2030, following the Habitat III UN conference, as far as the shift from a built environmentfocused approach to heritage towards a vision not exclusively based on material aspects (Vecco 2010). Heritage has been included as one of the targets for the Sustainable Development Goal Sustainable Cities and Communities, SDG 11, i.e. the target Strengthen efforts to protect and safeguard the world's cultural and natural heritage (UN 2015). Because of the intertwined nature of tangible and intangible 
heritage, built environment underpins a combination of values, such as cultural diversity, national and/or local identity, sense of belonging, which from one side deserve being made available to future generations (inter-generational justice principle), from the other hand, actively contribute to reinforcing communities' resilience. Indeed, heritage and related community values are inextricably linked to the local assets, thus creating opportunities for a sustainable socio-economic development (Bosone and Fusco 2020; Trillo 2012). Threats to heritage are sometime deliberate, because by destroying tangible heritage, the intangible values of the community are also challenged. This concept has been explicitly recognized at international level by the International Criminal Court in 2016 (Fusco and Trillo 2020; ICC 2016; Trillo 2019). Alongside deliberate destruction, tangible heritage is challenged either by rapid urbanization or abandonment and decay, thus making the case for a higher need of accurate documentation through the available technologies and means.

In recent years, using technology has become crucial in the construction industry, including heritage conservation (Pocobelli et al. 2018; Udeaja et al. 2019; UNESCO 2009). Evidence has revealed that digital technologies supports the holistic documentation and planning for the preservation of heritage sites (Acierno et al. 2017; Ioannides et al. 2018). In some cases, digital technologies may also support the work of conservationists, architects, archaeologists, planners and engineers. Despite scholarship on the subject is growing, still paucity of systematic reflection based on different extant cases exists, thus reducing availability of support in the decision-making process regarding the most appropriate technology. Scholarship tend to focus either on specific technologies or on categories of heritage, while this paper gauges different solutions with the aim to guide professionals in the selection of the most suitable to match their specific needs on a variety of heritage.

To achieve this goal, this paper compares a sample of digital platforms, including dataset suitable to support heritage documentation, both for historic and traditional architecture, and archeological sites. Although the discussion starts by providing the reader with a taxonomy of the different heritage assets, the paper does not prioritize any particular asset. Indeed, the focus is on, what kind of digital technologies are the most suitable to support different types of heritage or to pursue different goals. Despite the huge potential of digital technologies for contributing to heritage conservation, there is a need for clarity on what should be used to achieve different goals and what is the best approach under various circumstances. In some cases, there is still complexity on what should be the most appropriate approach to investigate, or to document, or to plan for heritage conservation. This lack of clarity does not help to make the most of limited resources. Issues relating to the gathering of heritage data and documentation include: technicality, accessibility and affordability. Digital technologies support a variety of outcomes, these may be less or more appealing, therefore may be used to promote heritage sites and archaeological areas or to support technical work. However, extremely detailed and technically and scientifically sound digital models may be of little use while trying to support heritage promotion for tourism development, whilst aesthetically appealing digital models can be only visually meaningful. This is of little help for the prioritization of digital technology in terms of promoting heritage and supporting architects and conservationist. Currently, there is a need to clarify what can be done with digital technologies and what should be prioritized, within the budget constraints.

At this aim, a bi-national team of five experts on digital technologies applied to different types of heritage worked collaboratively to gather the case studies in this paper and to analyse them comparatively, then findings were discussed with a larger panel of experts in the field. Case studies are digital platform implementing digital technologies for heritage conservation in Jordan. Jordan is a Middle East and North Africa (MENA) country and has been chosen as unit of analysis, because of the huge potential of digital technologies for heritage documentation. MENA countries experience threats to heritage that are higher than in other contexts, thus creating the need for an increased use of digital technologies for heritage documentation (Ipert 2016; Mazzetto 2018). Jordan is considered an emerging developing country, with all the development and urban projects that are running and the waves of refugees due to different political, social, economic reasons. The demand for more land for agriculture and development projects like roads and dams is directly affecting cultural heritage, therefore, local institutions are willing to develop their technical capacities, and learn from international case studies on how to integrate modern technology in cultural heritage protection projects (Sheldrick and Zerbini 2017). Furthermore, digital technologies can be used in support of planning for heritage conservation in a more effective way, and it is anticipated that currently Jordan is experiencing a renewed interest in implementing a recent law for heritage protection, including exploration of digital solutions. Finally, digital technologies allow promoting heritage beyond its materiality, bearing in mind limitations in terms of authenticity (Nikonova and Biryukova 2017).

The discussion on digital platforms currently available in Jordan allows for highlighting strengths and limitations 
of different approaches and methodologies, thus drawing lessons for addressing the strategic choice of the most appropriate digital solution under different circumstances and in different contexts. In fact, there is a difference between tools and instruments to be used to achieve goals such as accuracy of the digital representation, effective and aesthetically appealing 3D virtual images, interoperability of the data with platforms used by planners and architects. Digital technologies can be used to gain accuracy in the data, for effective documentation of heritage and to save time and money. The review of different cases offers a reflection on what should best adopted for achieving different goals. Thus, outcomes from this study may be used by conservationists, architects, planners, and engineers working at the interplay of heritage conservation and digital technologies internationally.

\section{Setting the Context: Heritage Conservation in Jordan}

Jordan is a MENA country, a region challenged by a variety of serious threats undermining the conservation of heritage, both archaeological and historical. Beside the conflicts and wars, heritage of the MENA region is vulnerable to growing threats. Urban and industrial development, agricultural expansion, looting and illicit trafficking, population growth and natural threats (R. Bewley and Kennedy 2013; Zerbini 2018). Therefore, recording and documenting of cultural heritage is a high priority in order to help heritage professionals and decision makers to protect those sites and evaluate their condition on the ground, specially to the sites which can't be visited. Heritage inventories also have an important role to play in influencing the decisions of policymakers who plan infrastructural development plans such as dams, roads residential areas and others.

Jordan is a country well known for its diverse and valuable cultural heritage assets. It is an urbanized country with the northern part historically more urbanized than the southern, which is largely a desert (The World Bank 2007). As a nation it is experiencing significant pressures in its cities including: increasing poverty, political events in the region limit migration opportunities out of the country in search of employment, rapid urban population growth and uncontrolled urban expansion (Shahateet and Partale 2019; The World Bank 2007). Such pressures represent a particular threat to the traditional historic cores and to their built heritage that are often abandoned or used increasingly inconsistently with the central function they have performed earlier in the life of the city (Ministry of Tourism and Antiquities and Bank 2005). This includes archaeological sites and the crusader castles to more recent urban fabric and traditional community public spaces that represent the Ottoman and post Ottoman architectural heritage and urban tissue. Under such circumstances, local communities lack an understanding of the value of heritage and therefore do not preserve their cultural assets. In a country like Jordan, cultural heritage resources require delicate treatment and conservation works, as these archaeological sites are continuously exposed to natural and human dangers that accelerate their deterioration.

At an international level, Jordan has shown commitment to the protection of tangible and intangible heritage. This includes the ratification of the UNESCO World Heritage Convention (1972) ratified in 1975 and the Convention for the Safeguarding of the Intangible Cultural Heritage (2003) ratified in 2006. The national legal framework concerning archaeological and heritage preservation in Jordan is defined by two separate laws under the Ministry of Tourism and Antiquities. The Department of Antiquities is the responsible entity for the implementation of the archaeological policy in Jordan (Al-Qaatarneh 2013). The Antiquities Law No. 21 for the year 1988 defines antiquities as "Any movable or immovable object which was made, written, inscribed, built, discovered or modified by a human being before the year AD 1750" (Ministry of Tourism and Antiquities 1988). It should be noted that the Law of Antiquities protects architectural heritage dating to pre$1700 \mathrm{AD}$; later monuments are not under legal protection, thus leaving without any safeguard significant layers of the built heritage, such as heritage belonging to Ottoman Period. The National Law 2005 for the Protection of Urban and Architectural Heritage is expected to reform the sector, providing standards for the protection of architectural and urban heritage, preparing a list of all the heritage locations, provide the necessary finances for restoration and fairly compensate the owners of heritage sites in order to encourage them to protect the buildings they own (Ministry of Tourism and Antiquities 2005) (Figure 1).

The country has witnessed several efforts for the conservation of its cultural heritage from international or local institutions to individuals using different techniques, and advanced technology is considered a tool for the documentation of cultural heritage. This discourse of heritage conservation and digital technologies has been influenced by the historical landscape described in this section. Local institutions in Jordan are willing to develop their technical capacities and learn from international case studies on how to integrate modern technology in cultural heritage protection projects (Sheldrick and Zerbini 2017). The 


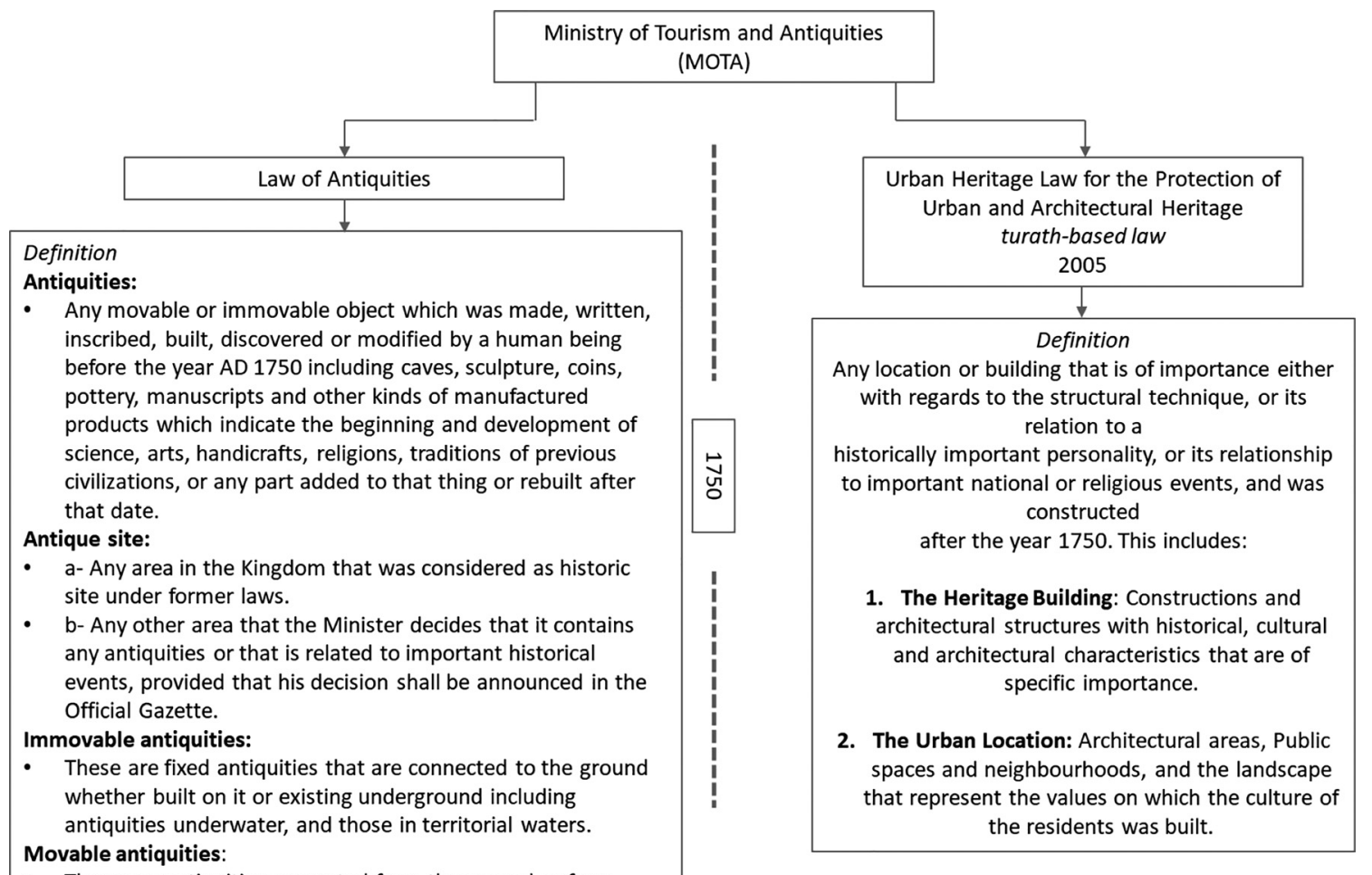

Figure 1: Jordan's heritage and archaeology legislation (Trillo et al. 2020)

employment of digital technologies, such as laser scanning, photogrammetry, satellite imagery is an active field which aims to answer the archaeological research questions, support in conservation works, reduce the time spent in extracting documents using the traditional method of document management or to provide more engaging experiences for the site presentation purposes to the visitors.

We will be presenting a few examples of projects which are aimed at documenting "antiquities" in Jordan-as defined by the Antiquities law-were implemented in Jordan in order to formulate a comprehensive understanding of the opportunities and limitation of using technology in this scope in the local context.

For the purpose of this paper, it is important to highlight that the definition of "heritage" according to the Jordan regulatory framework is slightly different from the international understanding of what heritage includes. Indeed, heritage would include both archaeological and non-archeological assets. In the following sections, while using the term "heritage", we will refer to the international UNESCO definition of heritage, i.e. including archaeological assets. In this regard, the protection law of archeological and non-archeological sites in Jordan does not present clearly for public and private sectors in Jordan. Furthermore, the lack of intellectual engagement with experts besides the capacity building of local community appears as barriers of establishing clear specifications for considering sites undoubtedly as heritage or as archaeological sites in Jordan. The line between heritage and archeological sites is determined by time and represented before and after $1750 \mathrm{AD}$. Case studies in this paper cover both groups of assets.

\section{Heritage Assets and Digital Technologies: a Possible Taxonomy}

This section provides the reader with a literature review on the categories chosen for the taxonomy of the different platforms investigates as case studies. At this goal, this section first discusses different definitions of tangible heritage assets, secondly, it provides the reader with an 
understanding of the current technologies mainly used for heritage conservation.

\subsection{Towards a Taxonomy for Tangible Heritage Assets (UNESCO)}

With the aim of presenting a taxonomy for tangible heritage assets to be used in the case study analysis (Section 5), this section will first discuss the official characterization and construction of "heritage" through UNESCO as a main vehicle. ${ }^{1}$ In the aftermath of the Second World War, the mobilisation of international cooperation in heritage conservation was channelled through UNESCO, initially to respect cultural property in the event of armed conflict (Calligaro 2014; Vecco 2010; Yahaya 2006). The preservation, collection and valorisation of cultural and natural heritage in view of the magnitude and gravity of the new dangers threatening them is the essence of the Preamble to the 1972 World Heritage Convention. This Convention is considered one of the most forward-looking conventions (Calligaro 2014; Labadi 2013; UNESCO, 1972). The World Heritage Convention reconciles previous definitions of cultural heritage and presents the definition as three categories: (1) monuments, (2) groups of buildings and (3) sites. After adopting the 1972 Convention, UNESCO drew up the World Heritage List including outstanding heritage in need of protection. In 1992, the ICOMOS was assigned in an advisory role to implement the World Heritage Convention. ${ }^{2}$ By the turn of the millennium, UNESCO had widened the concept of cultural heritage to include cultural landscapes, canals, and routes, as well as modern, rural and industrial architecture.

\footnotetext{
1 The preeminent role of UNESCO provides an internationally accepted operational definition of the term "heritage" through its directives, charters and international resolutions introduced over the last few decades. It is within this context that UNESCO began its significant contributions to the adoption of a series of international conventions, recommendations, and declarations that have led to the development of general international law. Marked by the first formal introduction of the expression of "cultural property", a direct reaction to the destruction of heritage in the Second World War was used in the Convention for the Protection of Cultural Property in the Event of Armed Conflict (The Hague, 14 May 1954) (UNESCO 1954).

2 The ICOMOS was established in 1965 by a group of primarily European architectural conservation experts (Gfeller 2013) establishing guidelines for introducing contemporary buildings into ancient sites. A further broadened conceptualisation is demonstrated in the ICOMOS Charter of the built vernacular heritage (1999) which recognises the traditional way by which communities house themselves as an expression of the culture of a community, of its relationship with its territory.
}

Key actors such as the European Union (EU) and the Council of Europe (CoE) have debated the meaning and scope of cultural heritage throughout the 1960s, 70s and 80s and into the 21st century (Calligaro 2014; PasikowskaSchnass 2018; Whitehead, Eckersley, and Zito, 2019; Zito, Eckersley, and Turner 2019). These organisations broadened the concept of cultural heritage in three main dimensions: material (artefacts, monuments), intangible (language, history) and political (expression of political values and principles) (Calligaro 2014). Numerous CoE heritage charters, conventions, and recommendations were introduced to encourage the protection, at national level, of the cultural and natural heritage. ${ }^{3}$ Indeed, the concept of tangible heritage as illustrated in the Table 1 below, can be considered as reasonably homogeneous at an international level intertwined with the international charters and documents (Petti, Trillo, and Makore 2019, 2020).

\subsection{Towards a Taxonomy for Digital Technologies Applied to Heritage Conservation}

To effectively assess and quantify the risk on cultural heritage, information needs to be accurately and comprehensively collected and managed. In particular, the spatial extent and location defined by co-ordinates of built heritage is essential for risk reduction and management. Digital technologies can be used as tools for achieving this (Myers 2016). As technology has advanced, heritage asset information and the development of new recording techniques have an increasingly important role to play in protecting heritage and especially in developing management tools for integrating heritage protection and land-use management (Pickard 2002). The use of digital technologies for documenting tangible heritage assets allows for the ability to frequently track changes of heritage in terms of form, function and sometimes location. This may involve "subjective interpretations that may need to be qualified, adjusted, and improved over time"(Myers 2016, p. 4). This is a compulsory part of nearly every cultural heritage conservation project as it was firstly mandated in the ICOMOS Venice Charter in 1964 (ICOMOS 1964). The impact of digital technologies to the domain of cultural heritage

3 This includes the (1985) Convention for the Protection of the Architectural Heritage of Europe, known as the Granada Convention. The identification of cultural heritage to be protected and inventoried is further recognized in European regional heritage norms, such as the Council of Europe's (1992) Valletta European convention on the protection of the archaeological heritage. 
Table 1: Taxonomy for tangible heritage assets (Petti, Trillo, and Makore 2019, 2020).

\begin{tabular}{|c|c|}
\hline Tangible heritage asset & Definition \\
\hline Archaeological & $\begin{array}{l}\text { Elements, structures and sites of an archaeological nature which are of outstanding universal value from the point } \\
\text { of view of history, art or science and from the historical, aesthetic, ethnological or anthropological point of view. } \\
\text { Elements of the archaeological heritage all remains and objects and any other traces of mankind from past epoch; } \\
\text { structures, constructions, groups of buildings, developed sites, moveable objects, monuments of other kinds as } \\
\text { well as their context, whether situated on land or under water. (UNESCO, World Convention, Article 1, 1972; } \\
\text { Valletta Treaty, Article 1, } 1992 \text { European Council) }\end{array}$ \\
\hline Monuments & $\begin{array}{l}\text { Architectural works, works of monumental sculpture and painting, elements or structures of an archaeological } \\
\text { nature, inscriptions, cave dwellings and combinations of features, which are of outstanding universal value from } \\
\text { the point of view of history, art or science (UNESCO, World Convention, Article 1,1972) }\end{array}$ \\
\hline Groups of buildings & $\begin{array}{l}\text { Groups of separate or connected buildings which, because of their architecture, their homogeneity or their place in } \\
\text { the landscape, are of outstanding universal value from the point of view of history, art or science; (UNESCO, World } \\
\text { Convention, Article 1,1972) } \\
\text { Groups of urban buildings: The towns which are no longer inhabited but which provide unchanged archaeological } \\
\text { evidence of the past, historic towns which are still inhabited (inhabited historic towns) and new towns of the } \\
\text { twentieth century (UNESCO February 1996: 8) }\end{array}$ \\
\hline Sites & $\begin{array}{l}\text { Works of man or the combined works of nature and man, and areas including archaeological sites which are of } \\
\text { outstanding universal value from the historical, aesthetic, ethnological or anthropological point of view. (UNESCO, } \\
\text { World Convention, Article 1, 1972) }\end{array}$ \\
\hline Cultural landscapes & $\begin{array}{l}\text { Combined works of nature and by humans, and they express a long and intimate relationship between people and } \\
\text { their natural environment. (UNESCO, World Convention, Article 1,1972) } \\
\text { Cultural landscapes fall into three main categories namely: } \\
\text { (1) clearly defined landscape designed and created intentionally by man } \\
\text { (2) organically evolved landscape } \\
\text { (3) associative cultural landscape (UNESCO Operational Guidelines 2008, Annex 3) }\end{array}$ \\
\hline Vernacular heritage & $\begin{array}{l}\text { Defined as: } \\
\text { (a) A manner of building shared by the community; } \\
\text { (b) A recognizable local or regional character responsive to the environment; } \\
\text { (c) Coherence of style, form and appearance, or the use of traditionally established building types; } \\
\text { (d) Traditional expertise in design and construction which is transmitted informally; } \\
\text { (e) An effective response to functional, social and environmental constraints; } \\
\text { (f) The effective application of traditional construction systems and crafts. (ICOMOS, Charter of the Built } \\
\text { Vernacular Heritage, 1999) }\end{array}$ \\
\hline Movable heritage & $\begin{array}{l}\text { All movable objects which are the expression and testimony of human creation or of the evolution of nature and } \\
\text { which are of archaeological, historical, artistic, scientific or technical value and interest (UNESCO, recommen- } \\
\text { dation for the Protection of Movable Cultural Property, 1978) }\end{array}$ \\
\hline
\end{tabular}

has increased speed and automation of the processes and practices that involve processing and presentation of digital heritage data. At present, a diverse range of existing digital technologies exist to perform digital surveying and produce 3D survey information of heritage assets (Udeaja et al. 2019). The taxonomy of a selected range of digital technologies is illustrated in the Table 2 below.

Results from a systematic review of digital technologies and heritage revealed that the emerging digital technologies researched in the field of cultural heritage included building information modelling (BIM), laser scanning, photogrammetry explored as a means to facilitate the modelling and documentation of monuments, sites and artefacts (Udeaja et al. 2019). Different heritage conservation projects utilize specific digital technologies in isolation or combined depending on the expected outcome. Variations of the use of digital technologies are evident in studies such as: the creation of 3D models for complex architectural shapes by using the terrestrial laser scanning (TLS) (Quattrini et al. 2015), digital point cloud model using the camera-equipped unmanned aerial vehicle and the TLS (Xu et al. 2014), the integration of 3D BIM and 3D geographic information system (GIS) (Baik et al. 2015) and the use of Virtual Reality and Augmented Reality (Noh, Sunar, and Pan 2009). However, the application of digital technologies to heritage assets still has gaps and limitations which become evident when investigating digital platforms and databases as explored later in this paper. 
Table 2: Taxonomy for digital technologies applied to heritage conservation (created by authors).

\begin{tabular}{|c|c|}
\hline Digital technology & Definition \\
\hline Satellite and aerial imagery and photography & $\begin{array}{l}\text { They permit accurate mapping of land cover and make landscape features understand- } \\
\text { able on regional, continental, and even global scales. }\end{array}$ \\
\hline Geographic information system (GIS) mapping & $\begin{array}{l}\text { A geographic information system, or GIS, relies on computer-based technology to pro- } \\
\text { duce, organize and analyze spatial information in the form of maps. GIS encompasses } \\
\text { database management, mapping, image processing and statistical analysis tools. These } \\
\text { tools allow users to see statistical data analyzed in relation to topographic and } \\
\text { geographic features and administrative boundaries. }\end{array}$ \\
\hline Photogrammetry & $\begin{array}{l}\text { It consists of techniques for interpreting, measuring, and modelling the objects based on } \\
\text { their acquired images. It provides both geometric and surface texture of the recorded } \\
\text { objects resulting in highly dense and textured 3D colored point clouds. }\end{array}$ \\
\hline Laser scanning & $\begin{array}{l}\text { A robotic total station, which can acquire data from the target at a high speed and in a } \\
\text { short time. Distance measuring is performed in regular networks without the need for } \\
\text { reflector. The fundamental basic in the operation of this instrument is based on the two } \\
\text { elements of distance and angle. Laser scanners have a field of view similar to human } \\
\text { eyes. They can be controlled by computer and integrated with a GPS. Laser scanners can } \\
\text { have a wide range of applications in cultural heritage documentation from small objects } \\
\text { to large complex buildings. }\end{array}$ \\
\hline Building information modelling (BIM) & $\begin{array}{l}\text { 3D model-based process that gives architecture, engineering, and construction (AEC) } \\
\text { professionals the insight and tools to more efficiently plan, design, construct, and } \\
\text { manage buildings and infrastructure }\end{array}$ \\
\hline 3D modelling and other augmented reality & $\begin{array}{l}\text { 3D modelling produces a 3D digital representation of any object or surface using a } \\
\text { particular software. Virtual reality and augmented reality reconstructing the historical } \\
\text { building and monument in the previous era, where the user experiences with the real } \\
\text { environment or virtual scene }\end{array}$ \\
\hline
\end{tabular}

\section{Research Methodology}

This study is based on a case study strategy and on a qualitative methodology, resting on both secondary (academic and non-academic literature, desk analysis of websites) and primary data (email exchange with experts working in the selected platforms). A single case study strategy articulated in multiple sub case-studies has been chosen (Yin 2011). The unit of analysis is a MENA country, Jordan. The reasons for choosing Jordan are mainly two and relate to context factors broadly explored in Section 2 . Being a MENA country, an area in which heritage is severely threatened by a variety of factors, Jordan has been included in various recent projects including the digitalization of heritage. In addition, national and local policy makers and experts are currently focusing on the implementation of the National Law on Heritage conservation. This is creating a momentum for heritage conservation in Jordan, thus triggering a discussion on which means are currently available in support of heritage conservation, including digital technologies (Udeaja et al. 2019). Digital platforms including Jordan as part of the database have been purposely selected, to cover both the variety of heritage categories and digital technologies as identified through the literature in the previous section. However, no significant platform has been left outside this study, hence, the sample is representative of the most relevant digital platforms for heritage conservation including Jordan as part of the database or exclusively focused on Jordan.

The sub-case studies have been initially analyzed by relying on the in-depth knowledge of digital platforms for heritage conservation in Jordan of the five authors. In fact, all authors have been working on different projects and from different angles, within diverse multi-national research teams. Two authors have worked for Mapping Digital Cultural Heritage in Jordan (Madih), a project aimed at gathering information on digital platforms on Jordan heritage, three authors are currently developing digital tools for enhancing effective conservation of Jordan vernacular and traditional architecture. They have decided to join their efforts on this study by putting together and discussing collaboratively all the available data accumulated over the years. Their firsthand knowledge has been complemented with informal discussions that researchers conducted with further experts working on the specific databases, wherever needed to complete the information gained through the desk analysis and most importantly, to verify and complement the secondary data. Table 3 presents the data utilized to discuss each sub-case study, thus showing the consistency across the cases. It is worth 
Table 3: Dataset used for the sub-case studies (created by authors).

\begin{tabular}{lll}
\hline Sub-case & Primary data & Secondary data \\
\hline MEGA-J & Primary data collected through Mapping Digital & Mega-J Website, Publications, Madih \\
APAAME & Cultural Heritage in Jordan (Madih) & \\
EAMENA & Primary data collected through Madih & APAAME Website, Publications, Madih \\
DAAHL & Primary data collected through Madih & EAMENA Website, Publications, Madih \\
RAEng & Primary data collected through Madih & DAAHL Website, Publications, Madih \\
& Personal knowledge gained by working on the & Publications \\
Zamani & project RAEng & \\
& Primary data collected through Madih complemented & Zamani website, Publications, Madih \\
RIWAQ & by further virtual discussion & \\
I AM & Virtual discussion & Riwaq Facebook page, Riwaq website, Brochure \\
Wadi Faynan & Virtual discussion & I AM Website, Flyers and brochures \\
GAIMS & Virtual discussion & Website \\
\hline
\end{tabular}

mentioning that the discussion with external experts has been conducted by exchanging emails, since this study has been developed during the COVID-19 lockdown, and has taken the form of informal discussion aimed at filling the gaps in the knowledge of the researchers. ${ }^{4}$

From Section 3, we have derived the two lists of heritage assets and of digital technologies most commonly used to support heritage conservation internationally, which will be covered with the chosen case studies. Drawing from the list of tangible heritage categories (Section 3.1) and from the list of digital technologies (Section 3.2) used for heritage planning conservation, we have derived the headings and mapping of the case studies against each category and supporting the comparative analysis conducted in Section 6. Each case study has been thoroughly analyzed, to identify weaknesses and strengths of each selected approach and methodology with respect to the type of heritage. The bi-national team of five experts had weekly discussion over a three months' time in order to achieve a shared understanding and evaluating the cases consistently. However, to avoid any bias due to excess of involvement in the case studies, the team has first analyzed and discussed as a team the chosen cases, then verified the findings by discussing them with further experts. The following Section 5 presents each case study individually, while Section 6 offers a comparative analysis of the

4 This paper has been conceived, developed and written during the COVID-19 pandemic (March 2020-January 2021). This circumstance has limited the researchers, who could rely mainly on virtual instruments and tools. Informal discussions with experts and key persons involved in the case studies took place virtually using various channels depending on convenience, availability and network connections. This included emails and online platforms. Where safe to do so, face to face discussions were organized.
10 platforms presented below. Section 7 gives concluding thoughts and makes recommendations.

\section{Case Studies Presentation}

This section presents the case studies, by drawing from the dataset presented previously in Section 4. Case studies are first presented individually, then discussed with a comparative approach in Section 6. The researchers have considered a total of 10 case studies, each with a different level of involvement, from a direct involvement in the development of the case (e.g., RAEng), to an indirect involvement with knowledge derived from having worked in the delivery of the project. The case studies are presented below (Sections 5.1 to 5.10).

\subsection{Middle Eastern Geodatabase for Antiquities, Jordan (MEGA-J)}

MEGA-J platform (accessible at www.megajordan.org) was launched in 2011. The Department of Antiquities (DoA), Getty Conservation Institute (GCI), and World Monuments Fund (WMF) launched the Middle Eastern Geodatabase for Antiquities, Jordan-MEGA-Jordan or MEGA-J which is a web-based geographic information system (GIS) (The Department of Antiquities of Jordan 2010). The fundamental aim of establishing MEGA-J was to support the DoA in the conservation, protection, and management of antiquities, with a secondary priority of supporting scholar research (Myers and Dalgity 2012). This happens through centralization of all the information about archaeological sites in Jordan in one open source easy-to-use platform 
managed by the DoA. MEGA-J assists in the evaluation and monitoring of development projects that take place near archaeological sites. The platform also displays the site name, general historical information, the site coordinates, and the buffer zone supported with tools for the user to measure the distances and areas if needed. Since its establishment, more than 100,000 sites were recorded. However, the system considers any monument recorded as a site which explains the huge number of records. Many of those sites were imported from an older GIS platform called JADIS, but in spite of the large number of records, shifting in coordinates and changes in location due to the importing process can be considered a real issue. Moreover, there are limited options available for the user to export the data, which may not be very practical.

Looking at MEGA-J sustainability measures, system maintenance and periodic hardware and software upgrades are always needed in similar projects as well as the continuous use by the DoA of the system through integration in DoA staff daily tasks (Myers and Dalgity 2012). As MEGA-J is a free open-access platform, whether we agree or not, many users and stakeholders find this a serious threat to the archaeological sites as it might increase the number of looting and site destruction cases in the country.

\subsection{Aerial Photographic Archive for Archaeology in the Middle East (APAAME)}

Aerial Photographic Archive for Archaeology in the Middle East (APAAME) (accessible at http://www.apaame.org/) is hosted on Flickr and evolved as part of a long-term research project to develop a methodology for discovering, recording, and monitoring archaeological settlements in the Near East but principally focusing on Jordan since 1978 (Bewley and Kennedy 2013; Hammer and Ur 2019). The project is directed by Prof. David Kennedy and Dr. Robert Bewley. APAAME missions fly each year in helicopters, with the Royal Jordanian Air Force, over certain areas to take high-resolution images of ancient settlements and landscapes in the country (Kersel and Hill 2020). More than 100,000 aerial photographs produced by APAAME are a great reference for researchers to understand the ancient settlements and study the rapid effect of development, changes, and disturbances over time (Bewley and Kennedy 2013; Kersel and Hill 2020). Moreover, the historical aerial photographs in the archive are geo-referenced based on the site information only, while the more recent photographs are based on the exact position of the photographer.
The search option is limited to the site name, the photographer name, date of the mission and site type. The researcher can view the photos distributed on the map of Jordan but not search using the geographical information. The archive is open access, but all images are watermarked with the APAAME logo along with the image information.

\subsection{Endangered Archaeology in the Middle East and North Africa (EAMENA)}

In 2015, APAAME collaborated with the Endangered Archaeology in the Middle East and North Africa (EAMENA) (accessible at http://www.eamena.arch.ox.ac.uk) based at the Universities of Oxford, Leicester, and Durham (Kersel and Hill 2020; Zerbini 2018) to use remote sensing techniques, historical aerial photographs, as well as published resources to identify, document, analyse, and monitor cultural heritage sites in the MENA region (Sheldrick and Zerbini 2017).

Several areas in the MENA region have physical accessibility restrictions, therefore remote sensing techniques is perceived as alternative solution of heritage sites monitoring and evaluation. EAMENA's approach is termed as a "rapid archaeological survey" (Bewley et al. 2016). This platform has more than 150,000 record and displays the main information about the site location, general information, and assessment of threats. If a researcher is interested in getting more information about a heritage record, they can submit a request via the registration form on the EAMENA website.

The main issue regarding the reliance on satellite imagery is the resolution, as the resolution of the satellite image varies depending on the time was taken or even for security reasons. Some photos may be blurry, like Al-Ghour area for example, while aerial imagery can provide higher resolution photos when looking at a site on smaller scale. Kersel (2020) argues that aerial coverage might be restricted due to flight restrictions, sensor size or other reasons.

\subsection{The Digital Archaeological Atlas of the Holy Land (DAAHL)}

The Digital Archaeological Atlas of the Holy Land - DAAHL is a regional, multinational database of archaeological site and project metadata available for the Levant. In 2014, it contained more than 27,000 sites and 60,000 site components from Cyprus, Israel, Jordan, Lebanon, southwestern Syria, the Sinai Peninsula, and the West Bank. The database includes almost 8000 sites from Jordan. 
It brings together experts in information technology including Geographic Information Systems (GIS) and the archaeology of the Holy Land (Israel, Palestine, Jordan, southern Lebanon, Syria, Cyprus, and the Sinai Peninsula) to create the first online digital atlas of the region held sacred to the three great monotheistic faiths - Judaism, Christianity, and Islam. The DAAHL database represents the first fully developed data node of the Mediterranean Archaeological Network (MedArch-Net), a project that envisions a series of archaeological atlases for the Mediterranean basin that share a common metadata structure. The MedArchNet is a series of linked archaeological information nodes from different countries and regions including Egypt, Turkey, Holy Land, North Africa, Spain, France, Italy and Aegean. Each of which contains a regional database of archaeological sites that share a common database structure in order to facilitate rapid query and information retrieval and display within and across nodes in the network.

\subsection{Royal Academy of Engineering (RAEng)}

RAEng is a project granted by the Royal Academy of Engineering for two years, the group of researchers include academics from Salford University, UK and Philadelphia University, Jordan including partners from the municipality of As Salt and industrial partners from both Jordan and UKOceanGreen and Bentley. The project can be accessed at www.herititjordan.com. The aim of the project is to develop a set of virtual models (3D models and BIM objects) suitable to support the construction sector and traditional architecture and heritage in Jordan. This will be achieved by; developing a new set of BIM (building information modelling) objects related to the traditional architecture heritage in Jordan, suitable to be used by engineers, and architects in the development of interventions on the built environment; creating a library of 3D models of exemplar buildings (Jordan heritage and traditional architecture), suitable to be used to promote the tourist image of Jordan. The BIM objects will provide our UK industrial partner-Bentley-with a new library available to practitioners operating in the conservation field; the 3D models will provide our Jordan industrial partners - the Jordan Tourism Board (JTB) and related network of operators in the tourism sector - with promotional tools to improve Heritage promotion in Jordan. This will be achieved by establishing a dedicated research centre, which will contribute to fill a gap in the current educational system of Jordan.

To achieve this goal, the Jordanian university and the JTB are partnering with the University of Salford, in the UK.
Through a series of e-meetings and workshops, the University of Salford is transferring knowledge by drawing from the Think Lab experience and run workshops with Jordanian experts to train them on using BIM for heritage promotion. The academics in Jordan are inputting into the project the know-how regarding the constructional adopted in the traditional architecture and Jordan heritage. The JTB will implement the project outcomes (3D models) to leverage the exploitation of the heritage for tourism development. Bentley and OceanGreen as industrial partners from UK and Jordan respectively will implement the project outcomes (BIM Objects) to leverage new knowledge and operational tools across engineers and architects Jordan community.

\subsection{International Augmented Med (I AM)}

International Augmented Med (I AM) integrates tourism, heritage, and technology. I AM (2012-2015). It is an international project aimed at developing innovative multimedia technologies for the management of cultural and natural heritage. Jordan represented by the Ministry of Tourism and Antiquities, Department of Antiquities (DoA) and Jordan University of Science and Technology (JUST) were involved along with other 14 international partners.

A pilot project was conducted in each of the seven partnering countries to demonstrate augmented realities techniques such as 3D modelling and virtual reconstructions of archeological sites, Video mapping, etc. were implemented. In the case of Jordan, the application was on a historical building that dates back to the nineteenth century in Irbid, currently serving as a museum.

\subsection{The Zamani Project}

The Zamani Project was established in 2005 at the University of Cape Town with the aim of documenting cultural heritage sites spatially in the Middle East and Africa (Wessels et al. 2014). The development of the digitalization project in Jordan included significant collaboration from diverse partners. The Geomatics Division, of the University of Cape Town in partnership with UNESCO Amman office, the Institute for Environmental Protection and Research, the Petra Development and Tourism Region Authority (PDTRA), and the Department of Antiquities (DoA) integrated all the documentation to create a 3D virtual tour of Petra World Heritage Site for scientific and tourist purposes (Wessels et al. 2014). 
The Petra project page on the Zamani Project website is accessible at (https://www.zamaniproject.org/site-jordanpetra.html). It is developed using a combination of data processed from photogrammetry, GIS data, terrestrial laser scanning, aerial photography, 360-degree panoramic images, as well as the traditional surveying methods. The intention of creating this platform is to support stakeholders in the site management, researchers in archaeological and scientific analysis, and visitors in their overall experience (Rüther et al. 2014). The Zamani Project is comprehensive in terms of data collection and production. Moreover, the documentation and advanced technological methods applied in the project are varied and target all types of audience. It can be seen as a documentation model that can be applied to other cultural heritage sites in Jordan. However, the outcome data provided to the project partners are not editable as it is only a copy. The training for the staff is only focused on specific parts of the project, not for the entire digital documentation process (Al Farajat 2020).

\subsection{RIWAQ}

RIWAQ is a Ramallah based non-profit organization whose main aim is the protection and development of architectural heritage in Palestine. Riwaq's Team comprises of 13 professionals, of architects, administrators, one historian and one archaeologist. The scope of Riwaq's work focuses on protecting and developing living architectural heritage for adaptive reuse (Salameh 2020). Digital technologies play a significant role in the work that Riwaq does. The team uses conventional methodologies for documentation which include on-site freehand sketching for plans, elevations and sections, followed by recording all the measurements in addition to photometric documentation for the building and its surrounding landscape. Thereafter, these sketches and measurements are transformed into digital drawings using the AutoCAD software (see Figure 2 below). For sites with high significance/importance in terms of history, architecture and aesthetic values, Riwaq commissions a company to undertake 3D laser scanning to create 3D point cloud model, such as the Crusader Church in $\mathrm{Al} \mathrm{Jib}$ and $\mathrm{Al}$ Hiqqiyeh in Qalandiya. ReCab and AutoCad Software was used and the plans and sections were extracted from the 3D point cloud model (see Figure 2). In other cases, Riwaq team uses the Photometry rectification technique. This technique is based on removing the perspective and the camera lens distortions, Riwaq team uses the software associated with the camera and the Hugin software for removing the lens distortion and the perspective distortion. Thereafter, using AutoCAD software rectified images are transformed into digital drawing scaled files to create sections and elevations. This technique was used in Hosh Al-Etem in Birzeit and Deir AlKhader in Gaza (see Figure 2).

In this instance using digital technology saves time and produce very accurate results, however, conventional methodologies of documentation are important since they
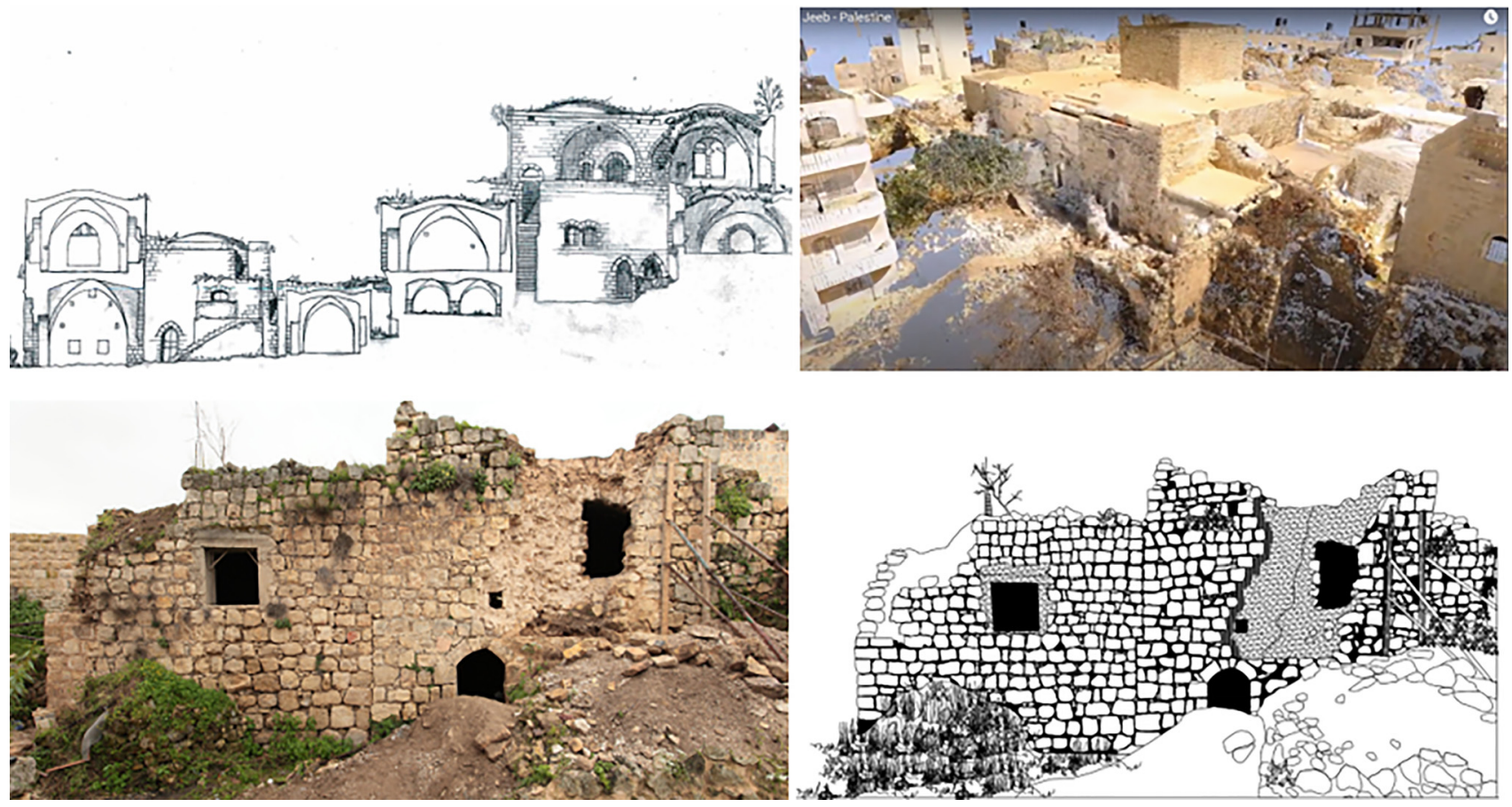

Figure 2: Riwaq work using digital technologies (Salameh 2020). 
give the chance for the architect/restorer to carry out onsite visual analysis using freehand sketches. These traditional techniques can allow for a better understanding of the site (Salameh 2020). Additionally, using freehand sketches creates an archival material for the site's condition from the eye of the architect/restorer (Salameh 2020).

\subsection{Wadi Faynan}

A comprehensive collection of 3D Models from the Wadi Faynan area in Jordan can be accessed on Sketchfab (https://sketchfab.com/sagesuav). They have been developed using digital photogrammetry by the School of Archaeology, Geography, and Environmental Science (SAGES) of the University of Reading, which includes high precision of 3D surveys and artifact models. The aim of this database is not only to document the cultural heritage of Faynan but also to make the cultural heritage of Wadi Faynan more accessible for people who have never visited the archaeological site. The project also plans to present the 3D models on a large screen in the Faynan Museum (The OPOF Team 2018). More development is intended to take place on the presentation of those 3D models in the future as part of the project.

\subsection{Gamification for Memorable Tourist Experiences (Med GAIMS)}

Med GAIMS is a project which uses digital technologies in cultural heritage documentation and promotion. With partners from Lebanon, Jordan, Spain, and Italy, the aim of the project is to renovate the tourism in the region through interactive approach. The project will run from (2019-2022) and will create 40 game applications in cultural heritage sites in the four partner countries. Although the project has not been implemented enough to support a thorough discussion on limitations and successes, still the researchers decided to include it into the case studies selection because of its unique goal of using heritage for leisure and entertainment through gamification.

\section{Comparative Analysis of the Case Studies}

This section presents a comparative analysis of the cases mentioned in the section above. A classification of the case studies is presented as a first phase of the analysis, by combining the two taxonomies derived from the literature review (Sections 3.1 and 3.2). This allowed us to develop a comparative discussion and appreciation of commonalities and differences, as well as deriving useful insights. The following Table 4 has been prepared by the five

Table 5: Case studies and goals/type of representation chosen (created by authors).

\begin{tabular}{lll}
\hline Sub-case & Goal & 2D vs 3D \\
\hline MEGA-J & Documentation-planning & 2D \\
APAAME & Documentation & 2D \\
EAMENA & Documentation-monitoring-planning & 2D \\
DAAHL & Documentation & 2D \\
RAEng & Documentation-planning-promotion & 3D \\
Zamani & Documentation-planning-promotion & 2D and 3D \\
RIWAQ & Documentation-planning-promotion & 2D \\
I AM & Promotion & 3D \\
Wadi Faynan & Documentation & 2D and 3D \\
GAIMS & Virtual discussion & 3D \\
\hline
\end{tabular}

Table 4: Mapping the case studies against the heritage and digital technologies categories (created by authors).

\begin{tabular}{|c|c|c|c|c|c|c|c|}
\hline & $\begin{array}{l}\text { Archeological } \\
\text { heritage }\end{array}$ & Monuments & $\begin{array}{l}\text { Vernacular } \\
\text { architecture }\end{array}$ & $\begin{array}{l}\text { Groups of } \\
\text { buildings }\end{array}$ & Sites & $\begin{array}{l}\text { Cultural } \\
\text { landscapes }\end{array}$ & $\begin{array}{l}\text { Movable } \\
\text { heritage }\end{array}$ \\
\hline Satellite imagery & $\begin{array}{l}\text { EAMENA } \\
\text { DAAHL } \\
\text { MEGA-J }\end{array}$ & $\begin{array}{l}\text { EAMENA } \\
\text { DAAHL }\end{array}$ & - & $\begin{array}{l}\text { EAMENA } \\
\text { DAAHL }\end{array}$ & $\begin{array}{l}\text { EAMENA } \\
\text { DAAHL }\end{array}$ & $\begin{array}{l}\text { EAMENA } \\
\text { DAAHL }\end{array}$ & - \\
\hline Aerial imagery & $\begin{array}{l}\text { APAAME } \\
\text { EAMENA }\end{array}$ & $\begin{array}{l}\text { APAAME } \\
\text { EAMENA }\end{array}$ & - & $\begin{array}{l}\text { APAAME } \\
\text { EAMENA }\end{array}$ & $\begin{array}{l}\text { APAAME } \\
\text { EAMENA }\end{array}$ & $\begin{array}{l}\text { APAAME } \\
\text { EAMENA }\end{array}$ & - \\
\hline $\begin{array}{l}\text { Photogrammetry-Laser } \\
\text { scanning }\end{array}$ & $\begin{array}{l}\text { Zamani } \\
\text { I AM } \\
\text { GAIMS } \\
\text { Wadi Faynan }\end{array}$ & $\begin{array}{l}\text { Zamani } \\
\text { I AM } \\
\text { GAIMS }\end{array}$ & $\begin{array}{l}\text { RAEng } \\
\text { RIWAQ } \\
\text { I AM } \\
\text { GAIMS }\end{array}$ & $\begin{array}{l}\text { RAEng } \\
\text { RIWAQ } \\
\text { GAIMS }\end{array}$ & $\begin{array}{l}\text { RAEng } \\
\text { RIWAQ } \\
\text { GAIMS }\end{array}$ & $\begin{array}{l}\text { RAEng } \\
\text { RIWAQ } \\
\text { Zamani } \\
\text { GAIMS }\end{array}$ & Wadi Faynan \\
\hline $\begin{array}{l}\text { BIM } \\
\text { Augmented reality }\end{array}$ & $\begin{array}{l}- \\
\text { I AM } \\
\text { GAIMS }\end{array}$ & $\begin{array}{l}- \\
\text { I AM } \\
\text { GAIMS }\end{array}$ & $\begin{array}{l}\text { RAEng } \\
\text { I AM } \\
\text { GAIMS }\end{array}$ & $\begin{array}{l}- \\
\text { GAIMS }\end{array}$ & GAIMS & $\begin{array}{l}- \\
\text { GAIMS }\end{array}$ & $\begin{array}{l}- \\
\text { GAIMS }\end{array}$ \\
\hline
\end{tabular}


Table 6: Further comparison of the 10 platforms showing strengths and lessons learned criticism and identified areas for future development (created by authors).

\begin{tabular}{ll}
\hline Strengths and lessons learned \\
\hline MEGA-J & $\begin{array}{l}\text { Free open-access GIS platform available for all to use and } \\
\text { explore. }\end{array}$ \\
& Used by department of antiquities frequently as a tool for \\
choosing the location of significant projects or roads near \\
archaeological sites. It helps in the evaluation and moni- \\
toring of development projects that take place near \\
archaeological sites. \\
First model or database for archaeological sites managed by \\
Department of antiquities. It can be used as a process de- \\
cision making tool.
\end{tabular}

APAAME It is a great reference for researchers to understand the ancient settlements and study the rapid effect of development and sites changes. Aerial imagery can provide higher resolution photos when looking at a site on a smaller scale.

EAMENA Remote sensing techniques can be an alternative solution of heritage sites monitoring and evaluation in case of war or conflicts.

More than 150,000 record, EAMENA database displays the main information about the site location, general information, and assessment of threats. Several records and database display the main information about the site location, and general information.

The system maintenance and update of the platform is very effective.

DAAHL Comprehensive review of the Holy Land, hence it links Jordan to the wider cultural context of the holy land. It includes regional, multinational database of archaeological site and project metadata for the Levant.

RAEng It supports and improves Heritage promotion in Jordan by using BIM which will contribute to fill a gap in the current educational system of Jordan.

BIM objects allow documenting not just the building, but also constructional details. It is to develop a set of virtual models (3D models and BIM objects) suitable to support the construction sector and traditional architecture and heritage in Jordan.

Zamani Very comprehensive in the area, both in terms of data collection and production, targeted both to the technical audience and to the general public (tourism promotion). For example, it provides a 3D tour for Petra by using a process control for many tools of documentation.

RIWAQ Thorough survey of less known traditional architecture, not yet subject to conservation restrictions and therefore endangered.

I AM Augmented realities techniques such as 3D modelling and virtual reconstructions of archeological sites, video mapping, etc. for tourism purposes.

Wadi Faynan Access to the cultural site for people who cannot access it physically.

Scientific documentation for fewer known areas is made available. 3D model Information available for sites such as Wadi Faynan

GAIMS The consideration of gaming application is a unique area of creativity and can be harnessed to maximize tourism promotion and target a wider audience.

\section{Criticism and identified areas for future development}

Sites were imported from an older GIS platform called JADIS, in spite the large number of records, shifting in coordinates and changes in location due to the importing process can be considered a real issue.

It is a free open-access platform, therefore some stakeholders may find this a serious threat to the archaeological sites.

System maintenance, periodic hardware and software upgrades. Might cause increase in the number of looting and site destruction cases in the country.

Server location is USA not Jordan.

The search function is not very flexible, you can't search by location, you only search by the name of the site.

Partially open-access.

As the resolution of the satellite image varies depending on the time was taken or even for security reasons, some photos may be blurred.

It includes a series of linked archaeological information nodes from different countries and regions. However, this information is limited.

BIM models need in-depth knowledge of constructional technologies, which cannot be acquired through laser scanning and photogrammetry. Time consuming and extensive fieldwork are necessary to produce sound BIM models of the chosen buildings. Data collection limited to few exemplar buildings, no systematic survey of the heritage city.

The database provided is not editable, it is only a copy.

Limited use of digital technologies, which could add value and simplify the data gathering and dissemination. The platform uses conventional methodologies for documentation.

Limited application in Jordan, only a pilot project on one heritage site.

Limited use of the digital techniques for the presentation of the project data.

The project is not implemented enough to be able to assess weaknesses. 

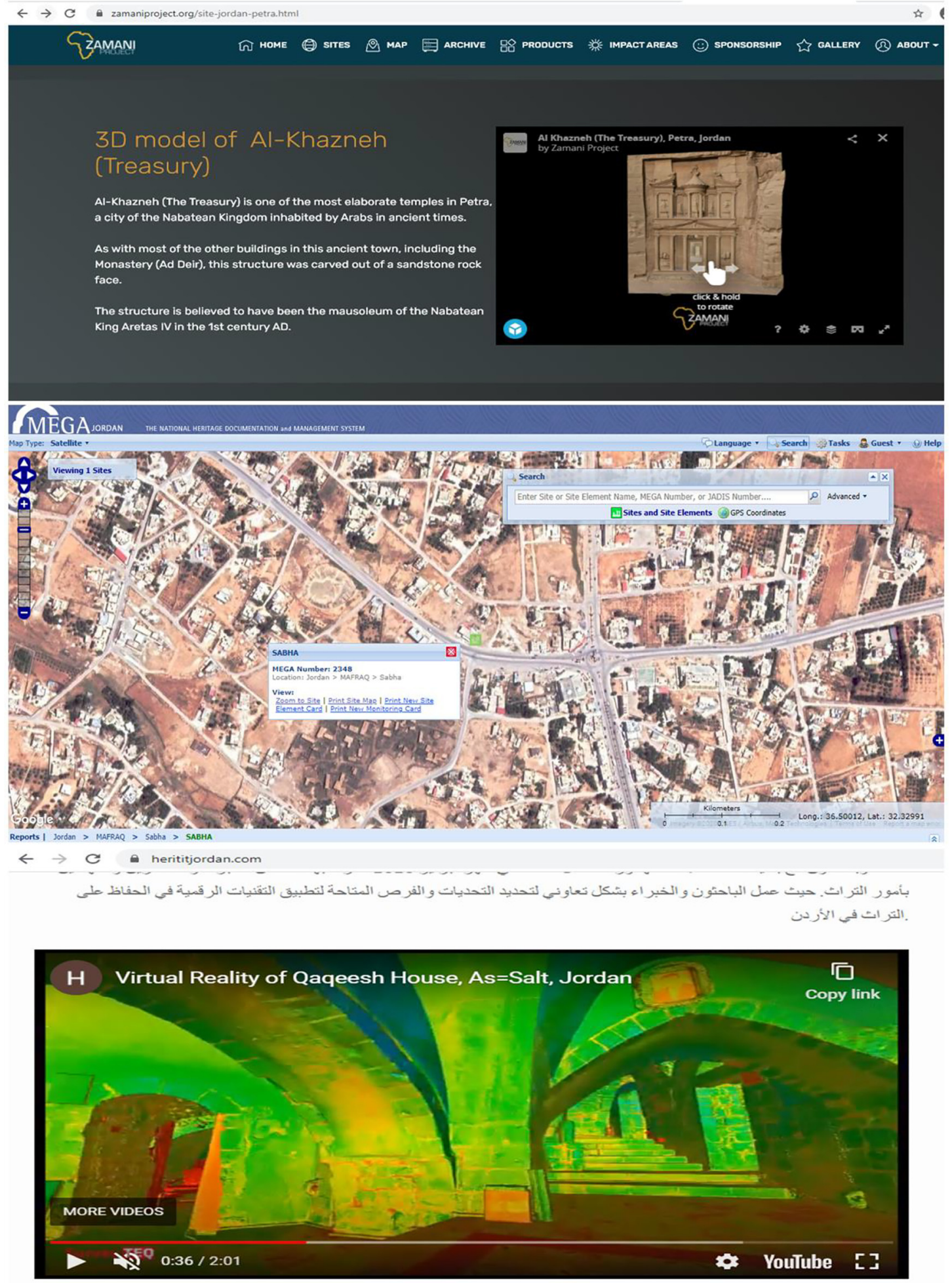

Experience a virtual tour of Qaqeesh House, As-Salt, Jordan (Created by our partners, SurveyTeq)

Figure 3: (Top) 3D model showing on the Zamani digital platform (www.zamaniproject.org/site-jordan-petra.html), (middle) Search tool showing in Mega Jordan digital platform (www.megajordan.org), (bottom) 3D virtual reality of traditional heritage house in As-Salt on the RAEng digital platform (www.herititjordan.com). 
researchers jointly through e-collaboration on skype over 12 weekly meetings, by analysing the case studies and mapping them against the categories of heritage and digital technologies implemented.

Table 4 shows how digital technologies applied to heritage are normally either aimed at producing technical support (EAMENA, DAAHL, APAAME, MEGA-J, Zamani, RAEng, RIWAQ, Wadi Faynan) or to create appealing images aimed at promoting heritage sites (I AM, GAIMS), also through gamification of heritage (GAIMS). I AM sits at the interplay of these two categories. Only one case applies Building Information Modelling to heritage conservation, i.e. RAEng. However, this was clear to the researchers, who are directly involved in the development of this case study and knew from the outset that they were filling a gap. One major observation is that the digital platforms focus on systematically documenting archaeological heritage (EAMENA, APAAME, DAAHL, MEGA-J, Wadi Faynan), and therefore are more likely to focus on either satellite or aerial imagery, and to remain at the larger scale, with little or no attention paid to the scale of the building of technologies. Some platforms focused on archaeological heritage, such as the Zamani project or I AM. These platforms demonstrate digitalization at the building scale. In so doing, they do not offer an extensive and wide range of archeological sites, but are focused on a few (one in the case of the Zamani project) assets, which are presented by using photogrammetry and laser scanning. Vernacular architecture and post-1750 heritage are so far not systematically considered by any platforms, thus leaving a serious gap in the body of knowledge on heritage in Jordan. Only I AM, RAEng and RIWAQ include this category of heritage, with RAEng and RIWAQ exclusively aimed at supporting the conservation of traditional and vernacular architecture.

As part of the next stage of analysis, the researchers have sought to understand which is the main goal, explicitly expressed or not, underpinned in the chosen databases. Five main goals have been identified as shown in Table 5 below: (1) documentation; (2) monitoring; (3) planning; (4) promotion; (5) gamification. Documentation is the main goal of all platforms orientated to offer direct support to conservationists, archeologists, architects and planners on heritage conservation, regardless of the category of heritage. EAMENA aims also at monitoring the state of archaeological assets. Some platforms, both gave attention to both archaeologic and non-archaeologic assets, as a means to offer instruments and tools for planning, by sharing useful data. However, it has to be highlighted that some experts are concerned about the criminalization of heritage data should it be widely accessible and shared for all. A relevant difference that can be observed between archaeological and non-archeological dataset is about the type of digital representation, either 2D or 3D as illustrated in Table 5. Systematic archeological survey mainly offers 2D maps, covering as already highlighted, large scale areas. Platforms digitalizing individual archeological assets or on vernacular heritage, as well as platforms aimed at grasping the non-technical user attention with aesthetically appealing graphic, mainly rely on 3D representation. Indeed, high levels of accuracy and reliability are keyspecifications of digital dataset of technically-orientated platforms. Consequently they are mainly aimed at contributing to the goals (1), (2) and (3) (documentation - monitoring - planning); while high level of aesthetical accuracy and appealing graphic are key-specifications of digital dataset of non-technically orientated platforms, mainly aimed at feeding into the goals (4) and (5) (promotion and gamification). It is therefore confirmed (key-finding 1) that having a clear understanding from the outset of which users will be targeted by the digital technologies for heritage conservation, and the specific goals that digital technologies will address, is essential in order to save resources and time.

In light with the aim of this study, i.e. to shed light on limitations and opportunities in the implementation of digital technologies in heritage conservation, Table 6 below gives a further comparison of the strengths and lessons learned and the criticisms and identified areas for future development. Ultimately, the comparative analysis has shown that there is no huge difference between platforms focusing on archaeological and non-archeological heritage, the key difference being between platforms aimed at achieving a systematic coverage of large-scale assets. These are mainly 2D based and tend to digitalize large archaeological sites through satellite or aerial images. Alternatively, platforms focused on either archeological or non-archeological assets, also implements 3D technologies and survey techniques suitable to capture the scale of the building (laser scanning, photogrammetry) (Figure 3).

\section{Conclusion and Recommendations}

In conclusion, the use of digital technologies can contribute significantly towards the sustainable heritage conservation and planning. The digital platforms mentioned in this study promote the achievement of the Sustainable Development Goals (SDGs), not just with respect to the target directly aimed at measuring the achievements on heritage conservation (Target 11.4), but also on SDG4 (education), SDG8 (economic growth) and 
SDG9 (industry and infrastructure). In fact, by being embedded into the wider strategies for socio-economic growth and education, heritage conservation policies will make a significant contribution to pursuing the goals of Agenda 2030, with digital technologies playing the role of boosting such a process. This paper concludes with a set of recommendations offering useful insights to conservationists, policy makers, architects, planners, and IT experts on digital technologies applied to heritage conservation. These recommendations are articulated based on analyzing related data, the process, impact and the projects outcomes as discussed below.

Recommendation (1). It is essential to clarify goals and final users of the digital technologies applied to heritage.

2D large scale systematic surveys, possibly repeated at regular intervals, are extremely useful to document and monitor large scale archeological assets, with the potential to be used for large scale heritage cities and landscapes. The tracking of sites can be achieved particularly specific heritage elements to highlight areas of attention. 3D digital objects are more appropriate at the building scale and should be used to document and monitor both archeological and architectural heritage with significant meaning. BIM technologies can help document buildings and related technologies but would require an in-depth level of knowledge of technical details. They cannot be derived by simply relying on photogrammetry or laser scanning. When properly understood, this knowledge can allow for the development of a sensitive and sustainable process of conservation. Finally, if platforms are mainly aimed at tourist promotion, there is no need for technical accuracy, and technical survey may not be essential. Instead, the implementation of highly sophisticated 3D augmented reality technologies is essential to raise the profile of heritage sites.

Recommendation (2). Georeferencing is a key-aspect of technical platforms aimed at documenting and monitoring large scale heritage assets.

The different georeferencing systems may create an issue of interoperability, and in the long-term, having a central documentation and monitoring digital centre would be extremely useful for supporting coordinated nation-wide heritage conservation strategies. Adopting a single standard for georeferencing digital objects and maps is highly recommended. This would enable a baseline to be achieved in different geographical regions of a country and therefore provide a consistent approach for heritage conservation.

Recommendation (3). Open-access platforms should not be used for vulnerable heritage.
Knowing the exact location of vulnerable heritage may support not only researchers and conservations, but also individuals who may use this crucial information for criminal activity and exploitation. It is highly recommended that, following the EAMENA lessons, a password is requested for accessing sensitive information and data, keeping a record of data requests and purpose for requests. It is possible to use this record to list the vulnerable sites based on the level of attention and support needed e.g. (from 1-10) where category one is highly need for support. Furthermore, knowledge exchange can be achieved by comparing other similar sites around the world.

Recommendation (4). Systematic use of digital technologies may support better heritage conservation and planning.

A systematic survey of heritage assets has so far been conducted mainly for archeological sites, with very little or no interest in conducting systematic survey on heritage towns and cultural landscape. Documenting and monitoring heritage towns and cultural landscape would be very helpful to support architects, planners and policy makers. Benefits include planning effective conservation strategies such as using techniques of building, materials, skills in conservation, and developing sustainable plans for heritage cities and for historic urban landscapes. A nonsystematic survey of exemplar buildings through BIM can help clarify the nexus between the scale of the building (and its constructional techniques and details) and the larger site. A blended approach relying both on 2D and 3D representations would help to achieve this goal.

To conclude, this set of recommendation is derived from the comparative analysis of 10 digital platforms focused on Jordan heritage, however, their applicability is transferable to the wider international context because they are not related to any context-specific issues. There is a huge need for accurate heritage documentation, more effective heritage conservation planning and heritage promotion. Digital technologies can help in achieving these goals, if they are appropriately selected and implemented in consistency with the expected result.

\section{References}

Acierno, M., S. Cursi, D. Simeone, and D. Fiorani. 2017. “Architectural Heritage knowledge Modelling: An Ontology-Based Framework for Conservation Process." Journal of Cultural Heritage 24: 124-33.

Al-Qaatarneh, M. 2013. "Conserving the Archaeological Heritage in Jordan Is the Mission of the Department of Antiquities." In Paper presented at the JOCHERA Final Conference, Amman, Jordan. 
Barrère, C. 2016. "Cultural Heritages: From Official to Informal." City, Culture and Society 7 (2): 87-94.

Bewley, R., and D. Kennedy. 2013. "Historical Aerial Imagery in Jordan and the Wider Middle East." In Archaeology From Historical Aerial and Satellite Archives, edited by W. Hanson and I. Oltean. New York, NY: Springer.

Bewley, R., A. Wilson, D. Kennedy, D. Mattingly, R. Banks, M. Bishop, and R. Mason. 2016. "Endangered Archaeology in the Middle East and North Africa: Introducing the EAMENA Project." In Paper presented at the CAA2015. Keep the Revolution Going: Proceedings of the 43rd Annual Conference on Computer Applications and Quantitative Methods in Archaeology. Newcastle University.

Calligaro, 0. 2014. From 'European Cultural Heritage' to 'Cultural Diversity'? The Changing Core Values of European Cultural Policy. Also available at https://www.cairn.info/revue-politiqueeuropeenne-2014-3-page-60.htm.

Delanty, G. 2010. The European Heritage from a Critical Cosmopolitan Perspective. Also available at http://www.lse.ac.uk/ europeanInstitute/LEQS\%20Discussion\%20Paper\%20Series/ LEQSPaper19b.pdf.

Gfeller, A. I. E. 2013. "Negotiating the Meaning of Global Heritage: 'cultural Landscapes' in the UNESCO World Heritage Convention, 1972-92." Journal of Global History 8: 483-503.

Graham, B., G. Ashworth, and J. Tunbridge. 2000. A Geography of Heritage: Power, Culture And Economy, 1 ed. Abingdon: Routledge.

Hammer, E. and J. Ur. 2019. "Near Eastern Landscapes and Declassified U2 Aerial Imagery." Advances in Archaeological Practice 7 (2), https://doi.org/10.1017/aap.2018.38.

Harvey, D. C. 2001. "Heritage Pasts and Heritage Presents: Temporality, Meaning and the Scope of Heritage Studies." International Journal of Heritage Studies 7 (4): 319-38.

Harvey, D. 2008. Right to the City. New Left Review, SeptemberOctober. Also available at https://newleftreview.org/II/53/ david-harvey-the-right-to-the-city.

Hosagrahar, J., J. Soule, L. F. Girard, and A. Potts. 2016. "Cultural Heritage, the UN Sustainable Development Goals, and the New Urban Agenda. BDC.” Bollettino Del Centro Calza Bini 16 (1): 37-54.

ICOMOS. 1964. International Charter for the Conservation and Restoration of Monuments and Sites (The Venice Charter 1964). Also available at https://www.icomos.org/charters/ venice_e.pdf.

Ioannides, M., E. Fink, A. Moropoulou, M. Hagedorn-Saupe, A. Fresa, G. Liestøl, V. Rajcic, and P. Grussenmeyer. 2018. “Digital Heritage. Progress in Cultural Heritage: Documentation, Preservation, and Protection." In Paper presented at the 7th International Conference, Nicosia, 2018. Cyprus.

Ipert, S. J. 2016. "Preservation and Digitization Activities in Arabicand Farsi-Speaking Countries." Preservation, Digital Technology \& Culture (PDT\&C) 45 (2), https://doi.org/10.1515/pdtc-20160016.

Kersel, M. M. and A. Hill. 2020. “Databases, Drones, Diggers, and Diplomacy: The Jordanian Request for a US Cultural Property Bilateral Agreement." Journal of Field Archaeology 45 (suppl1): 101-10.

Labadi, S. 2013. UNESCO, Cultural Heritage, and Outstanding Universal Value Value-Based Analyses of the World Heritage And Intangible Cultural Heritage Conventions (978-0-7591-2256-7).
Also available at https://epdf.tips/unesco-cultural-heritageand-outstanding-universal-value.html.

Mazzetto, S. 2018. "Heritage Restoration as a Tool to Promote Architectural Identity in the Gulf Regions." Preservation, Digital Technology \& Culture (PDT\&C) 47 (1): 3-11.

Ministry of Tourism and Antiquities. 1988. Law of Antiquities No. 21 for the Year 1988. Also available at https://www.unodc.org/res/cld/ document/law-ofantiquities_html/Law_of_Antiquities-1-_ jordan.pdf.

Ministry of Tourism and Antiquities. 2005a. Law No. 5 of 2005 on the Protection of Architectural And Urban Heritage.

Ministry of Tourism and Antiquities and Bank. 2005b. Salt, Detailed Description of the City Revitalisation Program. Salt, Jordan.

Myers, D. 2016. "Heritage Inventories: Promoting Effectiveness as a Vital Tool for Sustainable Heritage Management." Journal of Cultural Heritage Management and Sustainable Development 6 (2): 102-12.

Myers, D., and A. Dalgity. 2012. "The Middle Eastern Geodatabase for Antiquities (MEGA): An Open Source GIS-Based Heritage Site Inventory and Management System." Changing Times 2 (1): 32-57.

Nikonova, A. A., and M. V. Biryukova. 2017. "The Role of Digital Technologies in the Preservation of Cultural Heritage." Muzeológia a kultúrne dedičstvo 5 (1): 169-73.

Nocca, F. (2017). "The Role of Cultural Heritage in Sustainable Development: Multidimensional Indicators as Decision-Making Tool." Sustainability 9: 1882.

Noh, Z., M. S. Sunar, and Z. Pan. 2009. "A Review on Augmented Reality for Virtual Heritage System." In Paper presented at the International Conference on Technologies for E-Learning and Digital Entertainment, Berlin, Heidelberg.

Pasikowska-Schnass, M. 2018. Cultural Heritage in EU Policies. Also available at http://www.europarl.europa.eu/RegData/etudes/ BRIE/2018/621876/EPRS_BRI(2018)621876_EN.pdf.

Petti, L., C. Trillo, and B. C. N. Makore. 2019. "Towards a Shared Understanding of the Concept of Heritage in the European Context." Heritage 2 (3): 2531-44.

Petti, L., C. Trillo, and B. N. Makore. 2020. “Cultural Heritage and Sustainable Development Targets: A Possible Harmonisation? Insights from the European Perspective." Sustainability 12 (3), https://doi.org/10.3390/su12030926.

Pickard, R. 2002. "A Comparative Review of Policy for the Protection of the Architectural Heritage of Europe." International Journal of Heritage Studies 8 (4): 349-64.

Pocobelli, D. P., J. Boehm, P. Bryan, J. Still, and J. Grau-Bové. 2018. "BIM for Heritage Science: a Review.” Heritage Science 6 (1): 30.

Rüther, H., R. Bhurtha, S. Wessels, and R. Schröder. 2014. "Spatial Documentation of the Petra World Heritage Site." In Paper presented at the AfricaGeo.

Shahateet, M., and K. Partale. 2019. Jordan's Tourism Sector Analysis And Strategy for Sectoral Improvement.

Sheldrick, E. N. and A. Zerbini. 2017. "A Heritage Inventory for Documenting Endangered Archaeology in the Middle East and North Africa." ISPRS Annals of the Photogrammetry, Remote Sensing and Spatial Information Sciences 4 (W2).

Smith, L. 2006. Uses of Heritage, 1st ed.London: Routledge.

The Department of Antiquities of Jordan. 2010. MEGA-Jordan. Also available at http://www.megajordan.org/.

The OPOF Team. 2018. Projects: Our Past, Our Future, All together in Faynan (OPOF). Also available at https://research.reading.ac. 
uk/archaeology-for-the-future/our-past-our-future-all-togetherin-faynan-opof/projects/?fbclid=IwAR07aDNreGzdaFx3 KGvZAPhGf1lzD-npABSU824HqEPm7vcdndtGnm9pXyl.

The World Bank. 2007. Project Appraisal Document on a Proposed Loan in the Amount of US $\$ 56$ Million to the Hashemite Kingdom of Jordan for a Cultural Heritage Tourism And Urban Development Project.

Trillo, C., R. Aburamadan, C. Udeaja, A. Moustaka, K. G. B. Awuah, and B. C. N. Makore. 2020. "Enhancing Heritage and Traditional Architecture Conservation through Digital Technologies. Developing a Digital Conservation Handbook for As-Salt, Jordan." In Paper presented at the New Metropolitan Perspectives: NMP, Reggio Calabria (Italy).

Udeaja, C., C. Trillo, G. Kwasi, D. Patel, K. Jha, B. C. N. Makore, and S. Gupta. 2019. Scientometric Analysis and Mapping of Digital Technologies Used in Cultural Heritage Field. In Paper presented at the ARCOM 2019, United Kingdom.

Udeaja, C., C. Trillo, G. Kwasi, B. C. N. Makore, D. Patel, L. Mansuri, and K. Jha. 2020. "Urban Heritage Conservation and Rapid Urbanization: Insights from Surat, India.” Sustainability 12 (6): 2172.

UNESCO. 1954. Convention for the Protection of Cultural Property in the Event of Armed Conflict with Regulations for the Execution of the Convention 1954. Also available at http://portal.unesco.org/en/ ev.php-URL_ID=13637\&URL_DO=DO_TOPIC\&URL_ SECTION=201.html.

UNESCO. 1972. Convention Concerning the Protection of the World Cultural And Natural Heritage. Also available at http://whc. unesco.org/en/conventiontext/.

UNESCO. 2009. Charter on the Preservation of the Digital Heritage. Also available at https://unesdoc.unesco.org/ark:/48223/ pf0000179529. page $=2$ https: $/ /$ unesdoc.unesco.org/ark:/ 48223/pf0000179529. page $=2$.

Vecco, M. 2010. “A Definition of Cultural Heritage: From the Tangible to the Intangible.” Journal of Cultural Heritage 11: 321-4.
Viejo-Rose, D. 2015. "Cultural Heritage and Memory: Untangling the Ties that Bind." Culture \& History Digital Journal 4 (2). https:// doi.org/10.3989/chdj.2015.018.

Wang, X., H. Ren, P. Wang, R. Yang, L. Luo, and F. Cheng. 2018. “A Preliminary Study on Target 11.4 for UN Sustainable Development Goals." International Journal of Geoheritage and Parks 6 (2): 18-24.

Wessels, S., H. Ruther, R. Bhurtha, and R. Schröder. 2014. "Design and Creation of a 3D Virtual Tour of the World Heritage Site of Petra." In Paper presented at the AfricaGeo, Jordon.

Whitehead, C., S. Eckersley, and A. Zito. 2019. European Policy Brief: Productions And Omissions of European Heritage. Also available at https://research.ncl.ac.uk/media/sites/researchwebsites/ cohere/CoHERE_D1.3_WP1-Policy-Brief_2019.pdf.

Yahaya, A. 2006. "The Scope and Definitions of Heritage: From Tangible to Intangible." International Journal of Heritage Studies 12 (3): 292-300.

Yin, R. K. 2011. Applications of Case Study Research. Sage.

Zerbini, A. 2018. "Developing a Heritage Database for the Middle East and North Africa." Journal of Field Archaeology 43 (S9-S18), https://doi.org/10.1080/00934690.2018.1514722.

Zito, A. R., S. Eckersley, and S. Turner. 2019. "The Instruments of European Heritage." In Dimensions of Heritage and Memory: Multiple Europes and the Politics of Crisis, edited by G. Bozoglu, M. Daugbjerg, S. Eckersley, and C. Whitehead. Abingdon: Routledge.

\section{Informal e-interviews}

Al Farajat A. (2020), Informal Discussion via Email, 22nd May 2020. Al Maslamani N. (2020), Informal Discussion via Email 22nd May 2020. Al Taher H. (2020), Informal Discussion via Email 22nd May 2020. Salameh M. (2020), Informal Discussion via Email, 28th May 2020. 